\title{
What the Catholic Church Has Learnt from Interreligious Dialogue
}

\section{Archbishop Michael Fitzgerald, M.Afr.}

\begin{abstract}
March 16, 2006
Address delivered at Brandeis University as part of the conference, "In Our Time: Interreligious Relations in a Divided World," co-sponsored by Brandeis University and by Boston College through its Center for Christian-Jewish Learning.
\end{abstract}

\section{Introduction}

My thanks to Dr. Jehuda Reinharz, president of Brandeis University, and Fr. William Leahy, president of Boston College, for the invitation to speak. I wish to congratulate them on this joint initiative to celebrate the fortieth anniversary of Nostra Aetate. It is my conviction that this seminal document is still relevant "in our time."

Nostra Aetate, the Declaration on the Relations of the Church to Non Christian Religions, which we are commemorating through this conference, took the Catholic Church by surprise. It was normal and only to be expected that Vatican II would take up some unfinished business from Vatican I, balancing the former Council's treatment of the Roman Pontiff with a closer look at the role of the episcopate, thus coming to stress collegiality. Ecumenical dialogue had been going on already for some time before the Council, so there was already a movement, a strong current, which Pope John XXIII could count on to support his desire for a Council that would be ecumenical in both senses of the word, reflecting the universal character of the Church and leading to unity among Christians. There was no corresponding interreligious movement, and in fact in the preparatory enquiries to set up the agenda for the Council very few bishops had mentioned relations with people of other religions. There were of course some pioneers, mainly people belonging to religious orders, including Jesuits and members of my own missionary Society, the Missionaries of Africa, who were working in the midst of populations that were not Christian. Yet these did not seem to have a great impact on the Church as a whole.

So it was that in the field of interreligious dialogue the Church as a whole had almost everything to learn. Nostra Aetate provided a basis, but being by nature a pastoral document the theological foundations for the action it proposed have to be sought elsewhere. Moreover, Christian communities throughout the world had to be reassured that the teaching of this Declaration was conformed to the Gospel and the Tradition of the Church.

The Secretariat for Non Christians, set up by Paul VI even before the document Nostra Aetate had been promulgated, set itself to accomplish this task, though Christian-Jewish relations remained under the Secretariat for Christian Unity, which had initiated this dialogue and had 
prepared the original draft of Nostra Aetate. Experts, such as Jean Daniélou and Henri de Lubac, both later to become Cardinals, were consulted. Theological and pastoral reflections were produced and made available to the public through a journal founded for this specific purpose: Bulletin. Secretariatus pro non Christianis, later to be renamed Pro Dialogo. Some special publications were prepared, including a series of Guidelines for dialogue with Muslims, with Buddhists, with Hindus, and for the Encounter with African Religions. These booklets, based on sound scholarship but generally simple in style, were designed to inculcate the new attitude towards other religions which the Church was to adopt according to Nostra Aetate.

Therefore in attempting to answer the question about what the Church has learnt from interreligious dialogue it will be well to approach the matter in two ways, one theological, the other more practical.

\section{Theological advances through the influence of interreligious dialogue}

In tracing the theological developments in the years since Nostra Aetate, I shall base myself mainly on the two official documents produced by the Secretariat for Non Christians, now known as the Pontifical Council for Interreligious Dialogue, namely The Attitude of the Church towards the Followers of Other Religion: Reflections and Orientations on Dialogue and Mission (1984, cited as DM) and Dialogue and Proclamation (1991, cited as DP). It will be necessary to take into account the teaching of the various Sovereign Pontiffs and also some documents emanating from other offices of the Roman Curia.

\subsection{A Trinitarian Foundation}

Dialogue and Mission states clearly that the fundamental motivation for dialogue is faith. "In the Trinitarian mystery, Christian revelation allows us to glimpse in God a life of communion and interchange" (DM 22). Reflection on the relations between the Divine Persons, where each Person is wholly turned towards the Others while remaining distinct, provides encouragement to imitate this model here on earth, not only within the Christian body, but with all people, including those who belong to other religions. Of course it will be realized that sinful human beings cannot hope to reproduce the perfect unity in diversity of the Trinity, but this does not take away the usefulness of striving in this direction.

In this context one may notice the tension that already exists in the Declaration Nostra Aetate between plurality and unity. Right from the very beginning cognizance is taken of the different religions but, at the same time, of the Church's "duty to foster unity and charity among individuals" (NA 1). The unity of humankind is emphasized, a unity of both origin and destiny, which yet leaves people religiously divided on the way to this common goal. In a similar way it is noticed that all human beings are faced with the same fundamental questions about human existence, thus indicating a certain unity in their aspirations and anxieties, but they turn to different religions for their answers. The beliefs and practices of these religions are regarded with respect, on account of the elements of truth and holiness they contain, but the uniqueness of salvation in Jesus Christ is maintained, for the Church is "in duty bound to proclaim without fail 
Christ who is "the way, the truth and the life (Jn 14:6)" (NA 2). It will be necessary to return to this tension again later. It has been mentioned here to show that if interreligious dialogue can take its lead from the Trinity, it can only be a very pale imperfect reflection of the richness of Trinitarian life.

\subsection{The Father's pervasive love}

"In God, the Father, we contemplate a pervasive love unlimited by space and time" (DM 22). This statement seems to me extremely important. It stresses the universality of God's love, both geographically and historically. It underlines a conviction that has grown since the Council, namely that the mercy of God cannot be confined. The First Letter to Timothy says that God wills the salvation of all (cf. 1 Tim 2:5), and this has to be taken seriously. For if God does really will that all be saved, then He must provide, in some way or another, the means to achieve this salvation. This has practical consequences for dialogue. It means that we can exclude no one from the possibility of responding to God and being united with Him. I have been struck by the moral uprightness, I would say even the holiness, of many people belonging to other religions. It must surely be said that this is the effect of God's merciful grace. If moral rectitude and holiness were to be confined to Christians, it would imply the condemnation of billions of people. Could the people of Boston accept that their Irish forebears, those in the Emerald Isle before the arrival of St Patrick, are all in hell? The same applies to Native Americans and all people who have followed their traditional religion. Traditional religion usually includes a high regard for ancestors, so it is important that these ancestors be respected. Indeed, it is precisely because God loves all people and wants their salvation that we must respect them, whatever their religious beliefs. This is the principle underlying Dignitatis Humanae, the Council's Declaration on Religious Liberty, although this document also stresses the obligation to search for the truth and to adhere to it once it has been found.

It is interesting to note that Pope John Paul II, preparing the Church for the Great Jubilee of the Year 2000, suggested dedicating a year to each Person of the Blessed Trinity. The final year of preparation was to be dedicated to the Father. In his letter introducing the preparation for the Jubilee, Tertio Millennio Adveniente, the Pope wrote:

The whole of the Christian life is like a great pilgrimage to the house of the Father, whose unconditioned love for every human creature, and in particular for the "prodigal son" (cf. Lk 15:11 -32), we discover anew each day. This pilgrimage takes place in the heart of each person, extends to the believing community and then reaches to the whole of humanity (TMA 49).

This extended vision is perhaps the reason why John Paul II suggested that the Year of the Father would be an appropriate time for holding meetings to which people of different religions would be invited. Accordingly, in October 1999, the Pontifical Council for Interreligious Dialogue organized, in the Vatican, an interreligious assembly focusing on the role of religions in society during the Third Millennium. The Pope himself presided over the concluding ceremony in St Peter's Square and in his discourse he mentioned that he saw interreligious dialogue as one of the signs of hope in the latter part of the century which was drawing to a close. He added, however, that more needed to be done to promote a culture of dialogue. "Greater mutual esteem and 
growing trust must lead to still more effective and coordinated common action on behalf of the human family" (Discourse to the Interreligious Assembly, Vatican City, 28 October 1999).

\subsection{A love communicated through the Word made Flesh}

The Incarnation, the fact that God has sent his Son into the world out of love (cf. 1 Jn 4:9), has always been central to Christianity. Yet John Paul II, taking up affirmations from Vatican II, gave new accents to this truth. Gaudium et Spes had already stated that, through the Incarnation, the Son of God has in a certain way united himself with every human being (cf. GS 22). The Pope echoed this in his first encyclical Redemptor Hominis (I quote, as it has been translated, in non-inclusive language. Please bear with me):

Man - every man without any exception whatever - has been redeemed by Christ. And with man - with each man without any exception, whatever - Christ is in a way united, even when man is unaware of it. Christ who died and was raised up for all, provides man, each and every man, with the light and strength to measure up to his supreme calling (RH 14).

This conviction, which could perhaps be termed a mystical vision of the unity of the whole of humankind in Christ, gives an added dimension to the dignity of the human person. This certainly influences, or should influence, the way Christians encounter people who do not belong to their own faith.

The Church has had to defend this truth in order to prevent its being watered down by the stream of relativism. This is the whole burden of the document Dominus Iesus issued by the Congregation for the Doctrine of the Faith in 2000. Should this reaffirmation of a central truth of Christianity be considered as a proof of an exclusivist attitude? To that question I would respond with some other questions. Is it exclusivist to believe in one God rather than in a multiplicity of gods? Is it exclusivist to believe in one Incarnation rather than in many? It is precisely because the Incarnation of the Son of God in Jesus Christ touches the whole of humanity that any other incarnation becomes superfluous. Christ remains the Way to the Father, a way that He has opened up for all people through his passion, death and resurrection.

One lesson that has been learnt from the practice of interreligious dialogue is that there is a need to be rooted in one's faith. The second document issued by the Pontifical Council for Interreligious Dialogue, Dialogue and Proclamation (1991), makes this clear:

The sincerity of interreligious dialogue requires that each enters into it with the integrity of his or her own faith. At the same time, while remaining firm in their belief that in Jesus Christ, the only mediator between God and man (cf. 1 Tim 2:4-6), the fullness of revelation has been given to them, Christians must remember that God has also manifested himself in some way to the followers of other religious traditions. Consequently, it is with receptive minds that they approach the convictions and values of others (DP 48)

The same document goes on to point out that, although the fullness of revelation is to be found in Jesus Christ, human beings, including Christians, have still to grasp this fullness. There is a continuous growth in consciousness of the truth, an unending process of learning. So it has been 
possible to define interreligious dialogue as a walking together towards the truth and collaboration in the service of humankind (cf. DM 13). This means that a further lesson from dialogue is that it requires an attitude of humility, not arrogance. Dialogue does not mean competition. There can be no place for rivalry, unless it is a rivalry for doing good, according to the Qur'anic injunction: "Had God willed he could have made you one community, but that He might try you with what He has given you, so vie with one another in good works. Unto God you will all return" (Q 5:48 ). St Paul has a similar thought, put negatively: "There must be no competition among you, no conceit; but everybody is to be self-effacing. Always consider the other person to be better than yourself, so that nobody thinks of his own interests first but everybody thinks of other peoples' interests instead" (Phil, 2:3).

Here I have been anticipating the second part of this talk, which will deal with practical matters. It is necessary to return to theological considerations.

\subsection{A love made present through the work of the Spirit}

The passage of Gaudium et Spes referred to above, meditating on the central role of Jesus Christ, the Son of God made man, concludes with a remarkable statement:

All this holds good not for Christians only but also for all men of good will in whose hearts grace is active invisibly (cf. LG 16). For since Christ died for all (cf. Rom 8:32), and since all men are in fact called to one and the same destiny, which is divine, we must hold that the Holy Spirit offers to all the possibility of being made partners, in a way known to God, in the paschal mystery (GS 22). [The translation used by the Catechism of the Catholic Church has "partakers ... of the Paschal Mystery," which is more accurate.]

Here the activity of the Holy Spirit is underlined. There has surely been a growth in pneumatology, the theology of the Spirit, since Vatican II, signaled by the encyclicals of John Paul II Dominum et Vivificantem and Redemptoris Missio. Dialogue and Mission notes that the Spirit acts in the depths of people's consciences accompanying them on their way to the truth. So the Spirit is active outside the visible boundaries of the Church. In fact it can be said that:

The Spirit both anticipates and accompanies the path of the Church which, nevertheless, feels itself impelled to discern the signs of his presence, to follow him wherever he leads and to serve him as a humble and discreet collaborator (DM 24).

Dialogue and Proclamation adds further reflection based on Vatican II. It notes that according to Lumen Gentium the good is found sown not only in the hearts of individuals, but also in the rites and customs of peoples (cf. DP 17 referring to LG 17). This can be attributed to the action of the Spirit for, as Ad Gentes (the missionary document of Vatican II) teaches, "Without doubt the Holy Spirit was at work in the world before Christ was glorified" (AG 4). So John Paul II could state that every authentic prayer is the work of the Spirit present in the hearts of people (cf. DP 27, citing the discourse of John Paul II to the Roman Curia after the Day of Prayer for Peace held in Assisi in 1986). 
It is obvious the impact that such a teaching can have on the practice of interreligious dialogue. The Christian is not going into this dialogue as someone who has everything meeting another who has nothing. Rather the Spirit in the Christian is able to meet the Spirit already present in the interlocutor belonging to another religious tradition. In the words of Cardinal Newman's motto: cor ad cor loquitur. Also, in the opposite direction, it seems to me that interreligious dialogue has helped the Church to be more aware of the activity of the Spirit and the importance of a sound pneumatology.

\subsection{The Church as the sacrament of God's love}

Since the Holy Spirit both anticipates and accompanies the Church in its mission, the role of the Church is really to discern the signs of the Spirit's presence, to follow the leads given by the Spirit, and to serve humbly and discreetly. The Church is indeed called to be a sign, a sacrament, of God's love to the world.

This understanding of the Church as sacrament, which Vatican II emphasized so strongly at the very beginning of Lumen Gentium, is the very foundation for interreligious dialogue. The Church is not a "club of the saved," to be cut off from the rest of the world, but a People, and indeed a pilgrim people, to which even those who do not know the Gospel are oriented or related in some way. So the Church has necessarily to be in dialogue. Hence the Declaration Nostra Aetate on the relation of the Church to other religions.

The Church has always been considered a prolongation of the Incarnation. If one meditates on the Incarnation taking the Baptism of Jesus as a starting point, one will see that the Son of God, without losing his identity, is immersed in not only in the waters of the Jordan but also in the stream of sinful humanity which craves redemption. Similarly with the Church. It too is immersed in humanity, and its true identity may not always be evident. It may be seen as a religion among the religions, and may indeed be called upon to act as such in today's pluralistic society. This is why it will be quite normal to find Christian leaders alongside Rabbis and Imams, Buddhist monks and Hindu swamis in interfaith councils. A pilgrim Church, its members are going forward, not alone, but in the company of many other pilgrims. In this fraternal journey, as John Paul II said at Assisi, "either we learn to walk together in peace and harmony, or we drift apart and ruin ourselves and others" (Discourse for the Conclusion of the World Day of Prayer for Peace, Assisi , 27.10.86, $\mathrm{n}^{\circ}$ 5).

Seen in this light, interreligious dialogue forms an integral part of the Church's mission. It is not an optional extra. As the document Dialogue and Mission states, it is one element of this "single but complex and articulated reality" which is the mission of the Church. It stands alongside presence and witness, prayer/contemplation/liturgy, service/diakonia, and proclamation/catechesis (cf. DM 13). Sometimes dialogue is suspect, since it is seen as an underhand way of trying to gain converts to Christianity and increasing the numbers of the Church. John Paul II made it clear that "dialogue does not originate from tactical concerns or self-interest, but is an activity with its own guiding principles, requirements and dignity" (Redemptoris Missio 56). This understanding of how dialogue fits into the life of the Church has, I think, been reinforced by the practice of dialogue, for where there is suspicion there can be no mutual confidence, and where confidence is lacking there can be no true dialogue. It is important 
to notice that the first-mentioned elements of the Church's mission - presence, prayer, service while they may lead up to explicit proclamation of God's love as manifest in Jesus Christ, are not essentially geared to this; they are not finalized by proclamation. The liturgy for instance is not celebrated in order to proclaim Jesus Christ, though Christ is indeed proclaimed in the eucharistic acclamation after the consecration. Similarly Christians do not engage in works of mercy as a pretext for preaching about Jesus Christ but, like the Good Samaritan, out of compassion for those who are suffering. So it can be said that interreligious dialogue is not aimed at bringing the partner in dialogue into the Catholic Church.

Through the practice of dialogue, therefore, its aim has been clarified. Perhaps this should be put in the plural. I would enumerate three aims of dialogue. First that people of different religions may live in peace and harmony together. Secondly that they may work together for the benefit of their brothers and sisters, at all levels, local, national and international. Thirdly that they may stimulate one another to respond generously to the call of God or the Absolute. It is with regard to this third aim that we can speak of conversion, not as a change of religion, but in the biblical sense of a purification of the heart. Care should be taken not to confuse this idea with the popular notion that the purpose of dialogue is to make Jews better Jews, Christians better Christians, Muslims better Muslims, and so on, for a change of religion cannot be excluded. The purpose is better defined as being to help each one follow with greater generosity the dictates of his or her own conscience.

\section{Learning from the Practice of Dialogue}

In this section I wish to treat of four Cs regarding interreligious dialogue: the necessary condtions for dialogue, the varied content of dialogue, the conduct of dialogue in its multiplicity of forms, and the continuity of dialogue which is in some ways a condition for its fruitfulness. All these dimensions of dialogue have become clearer as the Church has engaged in this aspect of its mission since Vatican II.

\subsection{Conditions for dialogue}

Nostra Aetate exhorts the members of the Church to enter into dialogue and collaboration with people of other religions "with prudence and charity" (NA 2). We are here at the level of attitudes and dispositions. It is interesting that Dialogue and Proclamation, when dealing with the dispositions required for a fruitful dialogue, puts in first place a balanced attitude (cf. DP 47). Experience has shown that if one is hypercritical, not seeing anything of the good that is contained in other religions, there can be no dialogue. This means that an effort has to be made to overcome negative attitudes, to dispel prejudice, to avoid stereotyping. One of the obstacles to dialogue listed by the same document is suspicion about the other's motivations for entering into contact. As has been noted above, such suspicion prevents the necessary climate of trust from developing. Another obstacle is a polemical spirit where the aim is to try to score points at the other's expense rather than to seek the truth together. 
On the other hand, a naïve attitude does not help either. There is no advantage in looking at other religions through rose-tinted spectacles. If we are ready to acknowledge the weaknesses in our own religious community, then we should not be surprised to find weaknesses also in other religious communities. We are not required to approve everything about the other religion. Where there is a climate of trust, then mutual criticism can be made. It may be possible, through exchange, to see the points criticized in a different light. It becomes apparent, for instance, that similar terms may be used, but with different meanings, so careful explanation is needed to avoid misunderstanding. Yet in some cases there may remain irreconcilable differences.

In this context it may be worthwhile to distinguish between ecumenical dialogue and interreligious dialogue. Though ecumenical dialogue and interreligious dialogue often go hand in hand, as in diocesan or the national conference offices for "ecumenical and interreligious affairs," their goal is different. Ecumenical dialogue aims at bringing all Christians into a unity faith sufficient for mutual recognition and for common celebration of the Eucharist. Interreligious dialogue cannot pretend to bring about a unity of all different religions; it can only help the followers of those religions to live in peace and harmony together, to collaborate in the service of humankind and to stimulate one another in responding to God.

Even so, it becomes understandable that a further condition for fruitful dialogue is openness. Where there is an attitude of self-sufficiency there will be no willingness to encounter the other as that other really is, and to be enriched by this encounter. Such a lack of openness, it has been learnt through experience, can lead to defensiveness or even to an aggressive stance towards the other. As has been said above, the Truth is greater than ourselves and is always before us. We have to be ready to learn from one another, acquiring new insights rather than learning new truths, in a process which will help us to deepen our own faith.

This leads to the recognition of a further condition for dialogue, namely a certain amount of knowledge. Those who have insufficient grounding in their own faith will be reluctant to expose themselves to interfaith encounter. At the same time a basic knowledge of other religions is required in order to avoid misrepresenting them. It has always been a concern of the Pontifical Council for Interreligious Dialogue that adequate formation be given for interfaith relations, in seminaries and in houses of formation for religious, but also in theological faculties which are frequented by a growing number of lay people. Recently, with the continent of Africa in mind, some guidelines have been produced for teaching about dialogue in general, about relations with Muslims and for pastoral concern with regard to African Traditional Religions. There is obviously a role here for universities also, and it is good to see that many universities have been developing this aspect of their theological curriculum, such as here at Brandeis University and Boston College . Again the Pontifical Council for Interreligious Dialogue has tried to contribute to theological reflection, and to dialogue among theologians, by organizing a series of colloquia: one in Pune, India, on Jesus Christ and the encounter with religions; a second, in Abidjan, Ivory Coast, on the meeting of Traditional Religions with the Gospel; and more recently, as a commemoration of Nostra Aetate, a theological reflection on religious plurality in the Western world, which took place in Mödling, near Vienna, Austria. In this regard, I would like to share with you my own conviction that it is not enough to give parallel courses on the different religions, Judaism, Islam, Buddhism, Hinduism, etc. It is necessary also to bring what has been learnt through the study of these religions into the teaching on Christian doctrine and morals. 
There are many themes that can be enriched by using, at least from time to time, a comparative approach, taking care however not to take elements out of their context. Of course, this means that the lecturers in Christian theology would need to become more familiar with other religions. It had always been my dream for the Council to facilitate such learning, a dream which remains unfulfilled.

To be complete, some mention must be made not only of subjective attitudes but of objective conditions for dialogue. Religious freedom is one such. It is obviously extremely difficult to engage in dialogue where there is a lack of freedom to practice one's religion openly. There will be a fear to express one's own opinions, to voice any kind of criticism which might jeopardize the limited freedom that does exist. Intolerance does not encourage openness. And even those who enjoy freedom may become frustrated when they see that in other countries their own coreligionists are suffering and yet dialogue does not seem to bring much help to this situation.

This leads to a final reflection. Something that is learnt quickly is that fruitful dialogue requires much patience. It is not an investment bringing quick returns. Very often it is necessary to start all over again, trying to build up trust once more, after setbacks or because of outside factors. In Christian-Muslim relations the events of $9 / 11$ and the affair of the cartoons spring to mind as examples. Failures or disappointments should not lead to discouragement. The fruits will come in their own good time.

\subsection{The content of dialogue}

Experience has shown that theological exchange is not the only form of dialogue, and indeed is not always the most appropriate, certainly not to begin with. Encounter at the human level is perhaps more significant than exchange on doctrinal differences. Hence the importance given to the dialogue of life, the sharing of joys and sorrows, of common concerns and preoccupations. Such contacts can develop into concerted action, where people of different religions work together in specific projects. These may not be always overtly religions, but religion will play its part. As examples mention could be made of associations for the care of the handicapped, or collaboration in relief work.

The dialogue of action just mentioned can be usefully supported by exchanges on social and moral questions. Such dialogues, about justice in trade relations, for example, or respect for the environment, or about educational matters or questions of bioethics, can lead to a common mind on certain issues and ad hoc alliances. In these times when the role of religion in the public forum is often questioned, it can be a great advantage when people of different religions are able to speak together with one voice. The final words of the section in Nostra Aetate on ChristianMuslim relations - "let them preserve and promote peace, liberty, social justice and moral values" (NA 3) - can be applied to relations with people of all religions.

Again, the respect which Nostra Aetate has inculcated for the values enshrined in other religions, has led to the development of a more spiritual form of dialogue, the dialogue of religious experience. The flourishing Monastic Interreligious Dialogue has revealed the common elements in the monastic way of life, even though the religious context, of Buddhism and Christianity, for instance, is very different. Yet this type of dialogue is not confined to monastics. Interreligious 
prayer can also be taken into consideration. This has developed considerably since the initiative taken by Pope John Paul II to invite people of all religions to Assisi in 1986 to pray for peace in the world. Of course there is need here for that "prudence" called for by Nostra Aetate, so that convictions are not sacrificed for the sake of an apparent harmony. Yet when such prayer is prepared well, and with sensitivity to the perspectives and requirements of different religions, it can be a powerful instrument for forging a unity of hearts.

\subsection{The conduct of dialogue}

One weakness of Nostra Aetate, it seems to me, is that by treating the religions in succession - it would have been difficult to do otherwise - the impression is given that dialogue is always bilateral: Christian-Jewish relations, Christian-Muslim relations, Christian-Buddhist relations, and so on. This does not always correspond to reality. Certainly in the last decades other forms of dialogue have developed.

Nostra Aetate was cautious about laying too much emphasis on Muslims' claim to descend from Abraham through Ismael, yet their conscious linking of their faith with that of Abraham is acknowledged. Abraham as a figure common to Jews, Christians and Muslims is in fact a feature of the dialogue that has developed in the last forty years. Many associations have grown up under the patronage of Abraham, La Fraternité d'Abraham in France being probably the oldest. Another group in France calls itself Les Enfants d'Abraham. In the UK a similar drive has given birth to the Three Faiths Forum. It is only right to recognize the good relations that exist in many countries among the three Abrahamic religions. Of course, the ongoing conflict between Israel and its Palestinian neighbours creates immense difficulty for fruitful trilateral relations, but where these exist they can make a contribution to peace in the world.

More important, perhaps, are multilateral relations, particularly in societies where a multiplicity of traditions exist side by side. In fact, where tensions exist between two communities, the presence of members of other communities can help to prevent conflicts from breaking out. In the period since the proclamation of Nostra Aetate a number of organizations, multi-religious in nature, have come into existence. As long as they respect the identity of each religion and do not attempt to unify all religions they can make a valid contribution to society.

A superficial reading of Nostra Aetate could lead one to think that only Catholics are involved in interreligious relations. In fact the document, while speaking of the Catholic Church, and the members of the Church, also addresses its exhortations to Christians in general. This is another instance where Nostra Aetate cannot be taken in isolation from other documents of the Second Vatican Council. Just as reference needs to be made to Dignitatis Humanae for the fundamental question of religious liberty, and to Lumen Gentium, Gaudium et spes and Ad Gentes for theological principles, so due account must be taken of the document on Christian unity, Unitatis Redintegratio. Not only is it necessary to recognize that other Churches and Ecclesial Communities are active in interreligious relations, but these relations have an impact on ecumenism. As the Directory for the Application of Principles and Norms of Ecumenism (1993) states: 
There are increasing contacts in today's world between Christians and persons of other religions. These contacts differ radically from the contacts between the Church and ecclesial communities, which have for their object the restoration of the unity Christ willed among all his disciples, and are properly called ecumenical. But in practice they are deeply influenced by, and in turn influence ecumenical relationships. Through them, Christians can deepen the level of communion existing among themselves, and so they are to be considered an important part of ecumenical cooperation $\left(\mathrm{n}^{\circ} 36\right)$.

\subsection{Continuity in dialogue}

The British solution to any problem is to set up a committee. It is hoped that by the time the committee has done its work and produced a report the problem will have solved itself. Yet committees and commissions have their usefulness, even for dialogue among people of different religions. In other words, structures provide the backbone for the flesh of dialogical activities.

Was this not the intuition of Pope Paul VI in setting up the Secretariat for Non Christians, even before Nostra Aetate had been solemnly approved by the Second Vatican Council? Was this not the reason why consolidation was given to Catholic-Jewish and Catholic-Muslim relations by creating the appropriate commissions to carry on the task of dialogue?

In the Catholic Church care has been taken to develop a network of commissions for interfaith work at diocesan and national levels. These commissions can be channels of communication, allowing the official teaching of the Church on interreligious dialogue to reach a wider circle of people, and at the same time allowing this teaching to be verified by experience at the grassroots level. Ideally, official structures, under the authority of the local bishop or the conference of bishops, do not stifle initiative. Their task is to promote, to encourage, to coordinate. They can prevent individual efforts from petering out, because they are the affair of one man or one woman without the support of the community. The commissions can also take care to involve new people, so that the dialogue may continue from one generation to the next.

There is a tendency among Catholics to expect to find similar structures in other religions, and they are disappointed when this is not so. There is nothing equivalent to dioceses in Buddhism, Hinduism, Islam or Judaism, so there will be no commissions at this level. Yet some structures do exist, and it is with these that relations have to be developed. The different schools of Zen Buddhism in Japan have a center of Zen Culture, and it is with this body that the spiritual exchanges have been organized. Some monasteries, such as Fo Guang Shan in Taiwan, have developed a network of foundations in different countries, and it becomes possible to deal with this organization as one would with a religious congregation in the Catholic church. Hinduism, or at least neo-Hinduism, has similar organizations such as the Ramakrishna Mission or the International Society for Krishna Consciousness. These also allow for the development of a dialogue which goes beyond individuals. Within Islam structures have been set up to facilitate dialogue, such as the International Islamic Forum for Dialogue, whose president is resident in Saudi Arabia, or the Permanent Committee of Al-Azhar for Dialogue with Monotheistic Religions. There are para-governmental bodies in Iran bringing Shi' ite Islam into dialogue with a variety of Christians. At the local level there are Councils of Mosques and similar bodies. There are also Sufi movements eager to dialogue with Christians. In the Jewish world there are bodies 
such as the World Jewish Congress and the Anti-Defamation League, each pursuing its own aim but desirous of contacts with people of other religions. There is the umbrella organization, the International Jewish Committee for Interreligious Consultations (IJCIC) which is the official partner for dialogue with the Vatican 's Commission for Religious Relations with Jews. Again there are also Councils of Synagogues. So despite fragmentation, it has been possible to find partners for a dialogue with some continuity.

\section{Conclusion}

If we are to ask ourselves what, in a nutshell, has been learnt through the practice of interreligious dialogue over the years since Nostra Aetate, how are we going to respond?

We might say first that the Church has learnt to be itself, a sign of God's saving presence in the world. It has become more convinced than ever that the content of the Christian faith is not to be watered down or compromised in any way, but that witness is to be given to the faith in the manner indicated by Peter: "Simply reverence the Lord Christ in your hearts, and always have the answer ready for people who ask you the reason for the hope that you all have, but give it with courtesy and respect and with a clear conscience" (1 Pet 3:15-16).

It could be added that the Church has learnt to relate to people of different religions in different ways, through neighborliness, through joint action, through the sharing of spiritual values, through formal discussions. It has further been discovered that this field is not confined to specialists, but is open to all. Of course, there is a greater consciousness of the preparation needed to conduct fruitful dialogue, but the degree of preparation needed will vary according to the level of the encounters.

Finally, I would say that the Church has learnt that the task of dialogue will never end. Just as the words of Jesus "the poor you have always with you" do not disqualify attempts to eliminate poverty, so the realistic assessment that religious plurality will persist does not make dialogue purposeless. As has been said above, we are on a journey together. We can continue this journey despite our differences, or even being enriched by our differences, until that day when history itself will come to an end, and the differences will have no further significance, for God will be all in all. 